\title{
HIV risk perception, risk behavior, and seroprevalence among female commercial sex workers in Georgetown, Guyana ${ }^{1}$
}

\author{
Keith H. Carter, ${ }^{2}$ Bhiro P. Harry, ${ }^{3}$ Michael Jeune, ${ }^{4}$ and \\ Devian Nicholson ${ }^{5}$
}

\begin{abstract}
A study of 108 female sex workers engaged in prostitution in Georgetown, Guyana, was made in April 1993. Based on interviews and procurement of blood samples, the study investigated relationships between HIV seroprevalences and AIDS knowledge, risk behaviors, client characteristics, and condom use. Street-walkers-as distinct from sex workers in bars, hotels, and Port Georgetown - tended to charge less, be worse off socioeconomically, and have clients who were similarly disadvantaged; they were therefore classified as belonging to a "lower" socioeconomic stratum, while the other workers were classified as belonging to a "higher" stratum. The overall HIV seroprevalence found among the sex workers was 25\% (95\%CI: $17 \%-33 \%$ ). But the 50 subjects in the lower stratum had a relatively high seroprevalence $(42 \%$, as compared to $10 \%$ among those in the higher stratum), accounting for 21 of the $27 \mathrm{HIV}$-seropositive subjects. Reported patterns of client origins (Guyanese or foreign), worker willingness to have sex without a condom, and condom use by clients differed by stratum. Participants in the higher stratum were more disposed to having sex without a condom. The workers' knowledge of what causes AIDS and how HIV is transmitted was low in both strata; substantial numbers of workers said they had contracted a sexually transmitted disease within the past two years or were users of illicit drugs. Condom use is reportedly less common among Guyanese than foreign clients, suggesting a greater risk of contracting HIV from Guyanese clients or infecting Guyanese clients with it. The HIV seroprevalence among workers who said they had only Guyanese clients was statistically greater than the rate among those who said they had only foreign clients. The HIV seroprevalence among those reporting more than five clients per week was statistically greater than among those reporting fewer. HIV seropositivity was relatively high among the 12 workers who said they used cocaine. Overall, the findings supported the view that interventions targeted at female sex workers and their clients should be strengthened-more specifically, that concerted efforts should be made to intensify condom promotion, distribution, and social marketing; to improve STD services that provide treatment and counseling for female sex workers; and to increase educational activities among the workers' Guyanese clients.
\end{abstract}

1 A Spanish version of this article will be published in this journal.

2 Pan American Health Organization, Georgetown, Guyana. Mailing address: Pan American Health Organization, Lot 8 Brickdam, Georgetown, Guyana.

3 Department of Psychiatry, Public Hospital, Georgetown, Guyana.

4 Communications Officer, East Street, Georgetown, Guyana.

5 Public Hospital, Georgetown, Guyana.
For the 1987-1992 period, the National AIDS Secretariat of Guyana reported that $280(71.8 \%)$ of the 390 confirmed AIDS patients in Guyana were males, and that at least $59 \%$ of these males were heterosexual (1). These data are consistent with the human immunodeficiency virus (HIV) being transmitted mainly by sexual intercourse (2).

Although females accounted for 110 $(28.2 \%)$ of these 390 AIDS cases, it should be noted that most of the female cases were reported in the last two years of the period (26 in 1991 and 53 in 1992). Overall, the annual AIDS 
incidence per million inhabitants in Guyana increased from 35.8 cases in 1988 to 83.2 in 1992, while the male:female ratio declined from 3.5:1 to $1.6: 1$ during the same period. Of the 265 male and 102 female patients whose ages were recorded in this period, $80.8 \%$ of the males and $85.3 \%$ of the females were in the 20-39 year age group (1).

As of 1992, Guyana's Bureau of Statistics estimated the national population at $717458(50.8 \%$ females and $49.2 \%$ males), with $31.1 \%$ of the inhabitants residing in urban areas. Among the country's 10 geopolitical regions, Region Four (where the capital, Georgetown, is located) had a total population of 297162 , with 126004 $(42.4 \%)$ being of East Indian descent and $142226(47.9 \%)$ of African descent. Within the female population of Region Four, those 15-29 years old accounted for $31.9 \%$ of the total, while those in the 30-39 year age group accounted for $12.1 \%$ (3).

The HIV seroprevalence among female commercial sex workers engaged in prostitution has been shown to vary in different parts of the world. Among other things, such variations have been associated with the worker's age, educational level, marital status, mobility, number of clients, time in practice, price, condom use patterns, history of sexually transmitted diseases (STDs), and drug abuse (4-14). Overall, however, investigations among female commercial sex workers have generally led to recommendations that educational and other HIV prevention activities be provided for such workers $(15,16)$.

It has been found that street prostitutes have been overrepresented in some studies of HIV seroprevalences in female sex workers, and it has been pointed out that differences in working conditions and work organization could influence the degree of risk to which they are exposed. More generally, both methodologic and logistic problems can thwart efforts to obtain a representative sample of the prostitute population; and, indeed, the samples in a number of studies that have recruited prostitutes from medical clinics must be regarded as potentially biased (14).

The marketing of both sex and recreational drugs is illegal in Guyana; and of course, as has been previously pointed out, connections between these two activities have important implications for HIV epidemiology and prevention $(17,18)$.

Female sex workers in Georgetown have recently been targeted by the police in an effort to remove them from the city's streets. Perhaps partly as a result, those who publicly offer their services in Georgetown tend to do so at specific locations: one group operates at a very limited number of hotels; a second group congregates along certain streets; a third works out of bars; and a fourth works at Port Georgetown, the country's main harbor, which provides access to visiting ocean-going vessels.

Our study found that those who congregated on certain streets generally charged the lowest fees and had the poorest socioeconomic statusprobably a reflection of their usual clients' socioeconomic situation. As a result, for purposes of the present survey these street workers were classified as belonging to a "lower" stratum; while those at the bars, hotels, and port (all of whom tended to charge higher fees) were classified as belonging to a "higher" stratum.

The study's primary purpose was to obtain baseline information on HIV seroprevalence among the group studied that could be used in future comparative studies and could also provide information relevant to health education efforts. Because empirical data on illicit drug use in Guyana was lacking, and because other studies have found a significant relationship between such drug use and HIV seroprevalences in female commercial sex workers, information about illicit drug use was solicited (10).

More specifically, the survey (conducted in April 1993) sought data that would provide an estimate of the HIV prevalence among female commercial sex workers in Georgetown; that would indicate the possible influence of the workers' socioeconomic status on HIV prevalences; and that would also provide information about these workers' knowledge, attitudes, beliefs, and practices relating to both HIV and AIDS.

\section{MATERIALS AND METHODS}

The study, carried out during the second and third weeks of April 1993 (including one Saturday evening), started with preliminary visits to known female commercial sex worker gathering sites. The sex workers found at those sites were contacted, apprised of the survey plans, and asked to encourage participation by their colleagues. Cooperation was also sought from hotel and bar managers and proprietors, who were assured that the survey had nothing to do with the police. In addition, assistance was obtained from the health officers at Port Georgetown, who encouraged sex workers at the port to participate.

The female commercial sex workers were given the dates and times (after 7 p.m.) of proposed visits to specific locales. Care was then taken to honor the arranged schedule. At two localities, repeat visits were requested by the sex workers to allow absent coworkers to participate. These repeat visits were made as requested.

The female sex workers were informed that an unlinked anonymous survey was being carried out in which they would be asked to answer a number of questions and donate a sample of blood. In return, each participant would receive G\$ 500 (US\$ 4.00) ${ }^{6}$ and a small packet of health-related items including an average of 10 condoms and pamphlets on HIV, AIDS, and other STDs. The payments were intended to compensate the participants for time lost and to reduce the number of refusals. Subsequently, none of the female sex workers, hotel managers, or bar proprietors refused our request for cooperation with the

\footnotetext{
6 G\$ 100 was equal to approximately US\$ 0.80 at the time of the survey.
} 
survey, although one of the sex workers refused to participate.

The sex workers soliciting clients on the streets were generally found to charge the lowest rates for their services (approximately G\$500); those at the hotels generally charged a rate ranging from G\$500 to G\$ 1500 ; and those at the bars and port generally charged G\$1500 or more. As previously noted, because of these rates and because the street-walkers appeared to have a lower socioeconomic status than the others, we decided to classify them as belonging to a "lower" stratum and the members of the other groups as belonging to a "higher" stratum.

Preliminary visits to the areas where sex workers were known to congregate suggested that approximately 500 female commercial sex workers were operating openly in the city. As a result, it was decided that the survey would continue until a minimum sample of 100 female sex workers had been interviewed. No limit was placed on the number to be interviewed from each stratum. All the female sex workers who volunteered were allowed to participate, but every effort was made to ensure that no one was interviewed more than once. The likelihood of double participation was reduced by the fact that most localities were visited only once, because most of the sex workers tended to work only at specific locations. At those sites where repeat visits were undertaken (at the request of the sex workers), the sex workers themselves identified coworkers who had been absent on the previous visit; and natural leaders among them helped to ensure that no one was given repeat interviews.

To cover the hotels and Port Georgetown, each of three previously trained interviewers (KC, $\mathrm{BH}$, and $\mathrm{MJ}$ ) were assigned specific areas for conducting interviews. To cover the street-walker areas and bars, a bus was employed to provide an appropriate site for interviews. Each interview questionnaire had previously been coded and taped to a similarly coded test tube for containing the participant's blood sample. The code on the questionnaire and cor- responding tube was covered, and was therefore not known to either the interviewer or the participant.

After the interview questionnaire was completed, each participating sex worker was directed to the survey technician $(\mathrm{DN})$, who obtained a $10 \mathrm{~mL}$ blood sample and gave the participant the \$G 500 remuneration and condoms or the health packet previously described. The test tubes with the blood samples were kept closed and upright in a rack at an average open-air temperature of $26^{\circ} \mathrm{C}$. After having provided the blood sample, each participant was given information about HIV/AIDS/STD transmission and prevention, was told that the result of her HIV test would not be individually available, and was advised to visit the Genitourinary Medicine Clinic at the Georgetown Public Hospital-where she could receive counseling, be tested for HIV and other STDs, receive the results of those tests, and be provided with condoms free of charge.

At the end of each night's activity, the blood samples collected were taken to the laboratory-where the samples were centrifuged and the resulting sera were stored under refrigeration. The maximum time that elapsed between blood extraction from a participant and refrigerated storage of that person's serum was approximately six hours. Subsequently, these serum samples were tested at the National Laboratory for Infectious Diseases using the Wellcozyme HIV 1 \& 2 ELISA method and the immunofluorescence assay (IFA) for positive confirmation (19). For purposes of data management, the EPIInfo program was used to receive and analyze the information provided on each participant's questionnaire and the HIV test results.

\section{RESULTS}

A total of 109 female sex workers were identified and recruited at the various survey sites. One individual refused to participate, leaving a total of 108. The distribution of these 108 participants in terms of HIV positivity, by socioeconomic strata and 19 characteristics surveyed, is shown in Table 1.

In all, 27 of the 108 participants $(25 \% ; 95 \% \mathrm{CI}=16.8 \%-33.2 \%)$ were seropositive for HIV. The substantially greater HIV seroprevalence found in the lower stratum $(42.0 \%$, compared to $10.3 \%$ in the higher stratum) was statistically significant $(\mathrm{OR}=6.3 ; 95 \% \mathrm{CI}=$ 2.1-20.87).

No participant was under 15 or over 39 years old, most being in the 15-29 year age group; and there were HIV positives in both age groups. By age group (15-29 versus 30-39), the differences in HIV seropositivity were not statistically significant. However, those 38 participants in the lower stratum who were 15-29 years old accounted for two-thirds of the HIV positives. Not surprisingly, their rate of HIV seropositivity was found to differ significantly from the seropositivity of participants in the higher stratum, both those in the younger age group $(\mathrm{OR}=6.3 ; 95 \% \mathrm{CI}=1.8-24.5)$ and those in the older group (OR = $15.3 ; 95 \% \mathrm{CI}=1.9-674.2$ ).

Similarly, marital status data revealed no significant differences in HIV seroprevalences until these data were broken down by strata. However, participants in the lower strata who reported having a stable relationship (past or present) exhibited a significantly higher HIV seroprevalence than lower strata participants reporting no stable relationship ( $\mathrm{OR}=7.7$; $95 \% \mathrm{CI}=1.4-77.5)$ or higher strata participants reporting either a past or present stable relationship $(\mathrm{OR}=10.7$; $95 \% \mathrm{CI}=2.8-48.5$ ) or no stable relationship (OR $=9.5 ; 95 \% \mathrm{CI}=1.7-93.7)$.

Likewise, no overall association was found between HIV seropositivity and education. (Only one participant, from the higher stratum, said she had no formal education.) However, the significantly higher HIV seroprevalences in the lower strata were found to carry across both educational categories. Specifically: no more than primary education, lower strata versus upper strata: $\mathrm{OR}=5.3,95 \% \mathrm{CI}=1.11-33.6$; more than primary education, lower strata versus upper strata: $\mathrm{OR}=7.3$, $95 \% \mathrm{CI}=1.5-46.6$; and lower strata 
TABLE 1. Results of the female commercial sex worker survey carried out in Georgetown, Guyana, in April 1993 showing the HIV seroprevalences among participants with various characteristics, by stratum. In each of the three right-hand columns, the numbers shown represent the number of HIV-seropositive sex workers over the total number of workers, the percentage positive, and the $95 \%$ confidence interval for this percentage

\begin{tabular}{|c|c|c|c|}
\hline Characteristic & Lower stratum & Higher stratum & Total \\
\hline $\begin{array}{l}\text { Age group (in years) } \\
15-29 \\
30-39\end{array}$ & $\begin{array}{c}18 / 38(47.4 \% ; 31.5 \%-63.2 \%) \\
3 / 12(25.0 \% ; 0.5 \%-49.5 \%)\end{array}$ & $\begin{array}{l}5 / 40(12.5 \% ; 2.3 \%-22.7 \%) \\
1 / 18(5.6 \% ; 0.0 \%-16.2 \%)\end{array}$ & $\begin{array}{c}23 / 78(29.5 \% ; 19.4 \%-39.6 \%) \\
4 / 30(13.3 \% ; 1.2 \%-25.5 \%)\end{array}$ \\
\hline $\begin{array}{l}\text { Marital status } \\
\text { Married and common law } \\
\text { Separated } \\
\text { Never had stable relationship }\end{array}$ & $\begin{array}{c}14 / 27(51.9 \% ; 32.9 \%-70.9 \%) \\
5 / 8 \quad(62.5 \% ; 29.0 \%-96.0 \%) \\
2 / 15(13.3 \% ; 0.0 \%-30.5 \%)\end{array}$ & $\begin{array}{l}0 / 15(0.0 \%) \\
4 / 25(16.0 \% ; 1.6 \%-30.4 \%) \\
2 / 18(11.1 \% ; 0.0 \%-31.6 \%)\end{array}$ & $\begin{array}{c}14 / 42(33.3 \% ; 19.0 \%-47.6 \%) \\
9 / 33(27.3 \% ; 12.1 \%-42.5 \%) \\
4 / 33(12.1 \% ; 0.1 \%-23.3 \%)\end{array}$ \\
\hline $\begin{array}{l}\text { Sex worker's educational level } \\
\text { None/primary school } \\
\text { Above primary school }\end{array}$ & $\begin{array}{r}9 / 27(33.3 \% ; 15.6 \%-51.1 \%) \\
12 / 23(52.2 \% ; 31.8 \%-72.6 \%)\end{array}$ & $\begin{array}{l}3 / 35(8.6 \% ; 0.0 \%-17.9 \%) \\
3 / 23(13.0 \% ; 0.0 \%-26.8 \%)\end{array}$ & $\begin{array}{l}\text { 12/62 (19.4\%; 9.5\%-29.2\%) } \\
15 / 46 \text { (32.6\%; 19.1\%-46.2\%) }\end{array}$ \\
\hline $\begin{array}{l}\text { Clients per week } \\
<5 \\
>5\end{array}$ & $\begin{array}{c}2 / 4 \quad(50.0 \% ; 1.0 \%-99.0 \%) \\
19 / 46(41.3 \% ; 27.1 \%-55.6 \%)\end{array}$ & $\begin{array}{l}3 / 37(8.1 \% ; 0.0 \%-16.9 \%) \\
3 / 21(14.3 \% ; 0.0 \%-29.3 \%)\end{array}$ & $\begin{array}{c}5 / 41(12.2 \% ; 2.2 \%-22.2 \%) \\
22 / 67(32.8 \% ; 21.6 \%-44.1 \%)\end{array}$ \\
\hline $\begin{array}{l}\text { Location service offered } \\
\text { Only Georgetown } \\
\text { Georgetown \& other regions of Guyana } \\
\text { Georgetown \& overseas }\end{array}$ & $\begin{array}{l}15 / 35(42.9 \% ; 26.5 \%-59.3 \%) \\
3 / 5(60.0 \% ; 17.1 \%-99.9 \%) \\
3 / 10(30.0 \% ; 1.6 \%-58.4 \%)\end{array}$ & $\begin{array}{l}6 / 34(17.6 \% ; 4.8 \%-30.4 \%) \\
0 / 6 \quad(0.0 \%) \\
0 / 18(0.0 \%)\end{array}$ & $\begin{array}{c}21 / 69(30.4 \% ; 19.6 \%-41.3 \%) \\
3 / 11(27.3 \% ; 0.9 \%-53.6 \%) \\
3 / 28(10.7 \% ; 0.0 \%-22.2 \%)\end{array}$ \\
\hline $\begin{array}{l}\text { Request condom use by clients } \\
\text { Not at all or occasionally } \\
\text { Most of time or always }\end{array}$ & $\begin{array}{c}3 / 9 \quad(33.3 \% ; 2.5 \%-64.1 \%) \\
18 / 41(43.9 \% ; 28.7 \%-59.1 \%)\end{array}$ & $\begin{array}{l}1 / 7 \quad(14.3 \% ; 0.0 \%-40.2 \%) \\
5 / 51(9.8 \% ; 1.6 \%-18.0 \%)\end{array}$ & $\begin{array}{r}4 / 16(25.0 \% ; 14.2 \%-35.8 \%) \\
23 / 92(25.0 \% ; 20.5 \%-29.5 \%)\end{array}$ \\
\hline $\begin{array}{l}\text { Condom possession by sex worker } \\
\text { Not at all or occasionally } \\
\text { Most of time or always }\end{array}$ & $\begin{array}{r}12 / 29(41.4 \% ; 23.5 \%-59.3 \%) \\
9 / 21(42.9 \% ; 21.7 \%-64.0 \%)\end{array}$ & $\begin{array}{l}4 / 22(18.2 \% ; 2.1 \%-34.3 \%) \\
2 / 36(5.6 \% ; 0.0 \%-13.1 \%)\end{array}$ & $\begin{array}{l}16 / 51(31.4 \% ; 24.9 \%-37.9 \%) \\
11 / 57(19.3 \% ; 14.1 \%-24.5 \%)\end{array}$ \\
\hline $\begin{array}{l}\text { Condom use by Guyanese clients } \\
\text { Not at all or occasionally } \\
\text { Most of time or always }\end{array}$ & $\begin{array}{c}5 / 16(31.3 \% ; 8.5 \%-54.0 \%) \\
16 / 34(47.1 \% ; 30.3 \%-63.9 \%)\end{array}$ & $\begin{array}{l}2 / 19(10.5 \% ; 0.0 \%-24.3 \%) \\
3 / 20(15.0 \% ; 0.0 \%-30.6 \%)\end{array}$ & $\begin{array}{r}7 / 35(20.0 \% ; 13.2 \%-26.8 \%) \\
19 / 54(35.2 \% ; 28.7 \%-41.7 \%)\end{array}$ \\
\hline $\begin{array}{l}\text { Sex without condom at client's request if } r \\
\text { Yes } \\
\text { No }\end{array}$ & $\begin{array}{r}7 / 18(38.9 \% ; 16.4 \%-61.4 \%) \\
14 / 32(43.8 \% ; 26.6 \%-60.9 \%)\end{array}$ & $\begin{array}{l}2 / 28(7.1 \% ; 0.0 \%-16.6 \%) \\
4 / 30(13.3 \% ; 1.1 \%-25.5 \%)\end{array}$ & $\begin{array}{r}9 / 46(19.6 \% ; 13.7 \%-25.5 \%) \\
18 / 62(29.0 \% ; 23.2 \%-34.8 \%)\end{array}$ \\
\hline $\begin{array}{l}\text { Would prefer to lose clients who refuse } \\
\text { condom use } \\
\text { Yes } \\
\text { No }\end{array}$ & $\begin{array}{c}20 / 43(46.5 \% ; 31.6 \%-61.4 \%) \\
1 / 7 \quad(14.3 \% ; 0.0 \%-40.2 \%)\end{array}$ & $\begin{array}{l}4 / 34(11.8 \% ; 1.0 \%-22.6 \%) \\
2 / 24(8.3 \% ; 0.0 \%-19.3 \%)\end{array}$ & $\begin{array}{c}24 / 77(31.2 \% ; 25.9 \%-36.5 \%) \\
3 / 31(9.7 \% ; 4.4 \%-15.0 \%)\end{array}$ \\
\hline $\begin{array}{l}\text { Knowledge: cause/transmission of AIDS } \\
\text { Appropriate answer } \\
\text { Inappropriate answer }\end{array}$ & $\begin{array}{c}3 / 4 \quad(75.0 \% ; 32.6 \%-99.9 \%) \\
18 / 46(39.1 \% ; 25.0 \%-53.2 \%)\end{array}$ & $\begin{array}{l}0 / 11(0.0 \%) \\
6 / 47(12.8 \% ; 3.3 \%-22.3 \%)\end{array}$ & $\begin{array}{c}3 / 15(20.0 \% ; 9.7 \%-30.3 \%) \\
24 / 93(25.8 \% ; 21.3 \%-30.3 \%)\end{array}$ \\
\hline $\begin{array}{l}\text { History of STD in past } 2 \text { years } \\
\text { Yes } \\
\text { No }\end{array}$ & $\begin{array}{r}7 / 16(43.8 \% ; 19.4 \%-68.1 \%) \\
14 / 34(41.2 \% ; 24.6 \%-57.8 \%)\end{array}$ & $\begin{array}{l}1 / 11(9.1 \% ; 0.0 \%-26.1 \%) \\
5 / 47(10.6 \% ; 1.8 \%-19.4 \%)\end{array}$ & $\begin{array}{r}8 / 27(29.6 \% ; 20.8 \%-38.4 \%) \\
19 / 81(23.5 \% ; 18.8 \%-28.2 \%)\end{array}$ \\
\hline $\begin{array}{l}\text { Considers self at risk of contracting HIV } \\
\text { Yes } \\
\text { No }\end{array}$ & $\begin{array}{l}10 / 25(40.0 \% ; 20.8 \%-59.2 \%) \\
11 / 25(44.0 \% ; 24.5 \%-63.5 \%)\end{array}$ & $\begin{array}{l}4 / 40(10.0 \% ; 4.5 \%-15.5 \%) \\
2 / 18(11.1 \% ; 0.0 \%-25.6 \%)\end{array}$ & $\begin{array}{l}14 / 65 \text { (21.5\%; } 16.4 \%-26.6 \%) \\
13 / 43(30.2 \% ; 23.2 \%-37.2 \%)\end{array}$ \\
\hline
\end{tabular}


TABLE 1. (Continued)

\begin{tabular}{lccc}
\hline \multicolumn{1}{c}{ Characteristic } & Lower stratum & Higher stratum & Total \\
\hline $\begin{array}{l}\text { Reasons for negative attitude regarding HIV risk } \\
\text { Religious }\end{array}$ & $0 / 2(0.0 \%)$ & & \\
Use condoms & $7 / 16(43.8 \% ; 19.4 \%-68.1 \%)$ & $0 / 0(0.0 \%)$ & $0 / 2(0.0 \%)$ \\
Lucky & $3 / 4(75.0 \% ; 32.6 \%-99.9 \%)$ & $1 / 5(20.0 \% ; 0.0 \%-55.1 \%)$ & $4 / 9(30.4 \% ; 20.8 \%-40.0 \%)$ \\
No reason given & $1 / 3(33.3 \% ; 0.0 \%-86.7 \%)$ & $1 / 6(16.7 \% ; 0.0 \%-46.5 \%)$ & $2 / 9(22.2 \% ; 8.3 \%-36.1 \%)$ \\
Use of cocaine & & & \\
Yes & $6 / 8(75.0 \% ; 45.0 \%-99.9 \%)$ & $0 / 4(0.0 \%)$ & $6 / 12(50.0 \% ; 35.6 \%-64.4 \%)$ \\
No & $15 / 42(35.7 \% ; 21.2 \%-50.2 \%)$ & $6 / 54(11.1 \% ; 2.7 \%-19.5 \%)$ & $21 / 96(21.9 \% ; 16.5 \%-27.3 \%)$ \\
Has knowledge of free condom availability & & & \\
Yes & $17 / 37(45.9 \% ; 29.9 \%-62.0 \%)$ & $0 / 30(0.0 \%)$ & $17 / 67(25.4 \% ; 20.1 \%-30.7 \%)$ \\
No & $4 / 13(30.8 \% ; 5.7 \%-55.9 \%)$ & $6 / 28(21.4 \% ; 6.2 \%-36.6 \%)$ & $10 / 41(24.4 \% ; 17.7 \%-31.1 \%)$ \\
\hline
\end{tabular}

with more than primary education versus higher strata with no more than primary education: $\mathrm{OR}=11.6$, $95 \% \mathrm{CI}=2.4-72.5$.

Nearly all the participants in the lower stratum reported having more than five clients per week, as compared to relatively few of the participants in the upper stratum. Overall, those participants reporting more than five clients per week had a significantly higher HIV prevalence than those reporting fewer clients per week $(\mathrm{OR}=3.5 ; 95 \% \mathrm{CI}=1.1-12.9)$.

No statistically significant difference was found between the HIV seroprevalence of those practicing commercial sex for more or less than 12 months. However, nearly all the lower stratum participants (six out of seven) who reported practicing commercial sex less than 12 months were HIV-positive. Their HIV seroprevalence was significantly higher than the seroprevalence of the 43 lower strata participants with longer experience $(\mathrm{OR}=11.2 ; 95 \% \mathrm{CI}=$ 1.1-533.0), the 20 higher stratum participants with less than 12 months' experience $(\mathrm{OR}=34.0$; 95\%CI $=2.3-$ 1650.7), and the 38 higher stratum participants with more experience.

Similarly, no statistically significant difference appeared between those operating only in Georgetown as compared to those working other areas. (Reported overseas locations included neighboring Suriname as well as English, French, and Dutch-speaking Caribbean islands.) However, all seropositives within the higher stratum said they had worked exclusively in Georgetown. Also, the statistically significant difference between seroprevalences in the lower and higher strata already noted was reflected in a statistically significant difference between the HIV seroprevalences of those in the lower and higher strata who said they had worked only in Georgetown $(\mathrm{OR}=3.5 ; 95 \% \mathrm{CI}=1.0-12.8)$.

Regarding condom use, ninety-two $(85.2 \%)$ of the participants said they usually or always asked clients to use condoms. However, no statistically significant difference was observed between the HIV prevalence of these participants and of those who said they made this request only occasionally or never. Fifty-seven (53\%) of the participants said they usually or always had condoms available; 54 $(61 \%)$ of 89 reporting said their Guyanese clients usually or always used condoms; and 61 (92\%) of 66 reporting said their foreign clients usually or always used condoms. However, perhaps owing to sample size, no statistically significant differences in HIV prevalences were found between those in the same stratum reporting different patterns of condom use.

A comparison of HIV seroprevalences and reported client nationality showed significantly higher HIV seropositivity among those with only Guyanese as compared to only foreign clients $(\mathrm{OR}=9.0 ; 95 \% \mathrm{CI}=1.1-401.3)$. However, the overall HIV seropositivity of those with both Guyanese and foreign clients did not differ signifi- cantly from that of those reporting only Guyanese clients.

Overall, 46 (42\%) of the participants (36\% of those in the lower stratum and $48 \%$ of those in the higher stratum) said they would have sex without a condom if the client requested it and they greatly needed money. However, $77(71 \%)$, including $86 \%$ of those in the lower stratum and $59 \%$ of those in the higher stratum, said they would prefer to lose a client who adamantly refused to use a condom. Interestingly, HIV seropositivity was significantly higher among these 77 than among the 31 who said they would keep the client $(\mathrm{OR}=4.2 ; 95 \% \mathrm{CI}=1.1-23.6)$.

Only 15 participants (13.9\%) knew AIDS to be the consequence of HIV infection and also knew two or more ways the virus could be transmitted. Three out of four lower stratum participants with this knowledge were HIVpositive, but none of the 11 higher stratum participants so informed were found to be infected $(\mathrm{OR}=4.4$; 95\%CI $=1.4-15.0$ ).

Regarding other STDs, no statistically significant difference was found in the HIV seroprevalences of those who said they did or did not have an STD within the preceding two years.

Sixty-five $(60 \%)$ of the participants said they considered themselves at risk of contracting HIV, while 43 (40\%) said they did not. A wide range of explanations-some relating to condom use, some to luck, and some to religion-were given by the 34 of these 43 participants who offered reasons 
why they did not consider themselves at risk of HIV (see Table 1).

Twelve of the sex workers (11.1\%) reported cocaine use. Although the HIV seropositivity was higher among those who said they used cocaine, the overall difference was not statistically significant (Fisher exact $P=0.0694$; $95 \% \mathrm{CI}=0.85-14.72)$. Two-thirds of those reporting cocaine use were in the lower stratum.

Overall, $67(62 \%)$ of the participants said they knew condoms were available free at the Genitourinary Medicine Clinic and the Guyana Responsible Parenthood Association. The difference between the HIV seroprevalences of those with and without this knowledge was not statistically significant. Nearly three-quarters $(74 \%)$ of those in the lower stratum reported having this information, as compared to only $52 \%$ of those in the higher stratum.

Table 2 provides data on the HIV prevalences of 28 participants who said they used either marijuana or cocaine. Within the two age groups studied (15-29 and 30-39 years), a larger share of the younger group (24 out of 78 as compared to 4 out of 30) reported being marijuana or cocaine users. However, marijuana or cocaine users in the upper age group had a higher rate of HIV seropositivity than nonusers in their age group, one that was statistically significant $(\mathrm{OR}=75.0$; 95\% CI $=2.2-4$ 074.7).

As can be observed in Tables 3 and 4, a larger percentage of higher stratum participants than lower stratum participants (48\% versus $36 \%$ ) said they would be willing to have sex without a condom; and a higher percentage of those reporting an STD within the past two years (as compared to those reporting no STD in that period) said they would be willing to have sex without a condom.

\section{DISCUSSION AND CONCLUSIONS}

The HIV seroprevalence found for the study participants was $25 \%$, with a $95 \%$ CI of $16.8 \%-33.2 \%$. This suggests,

TABLE 2. Survey results showing HIV seroprevalences among participants who reported using cocaine or marijuana or not using either drug, by age group. In the two right-hand columns, the numbers shown represent the number of HIV-seropositive sex workers over the total number of workers and the percentage that was seropositive

\begin{tabular}{lcc}
\hline $\begin{array}{l}\text { Age } \\
\text { group }\end{array}$ & $\begin{array}{c}\text { Reported users of } \\
\text { marijuana and/or cocaine }\end{array}$ & $\begin{array}{c}\text { Reported users of neither } \\
\text { cocaine nor marijuana }\end{array}$ \\
\hline $15-29$ & $6 / 24(25.0 \%)$ & $17 / 54(31.5 \%)$ \\
$30-39$ & $3 / 4(75.0 \%)$ & $1 / 26(3.8 \%)$ \\
Total & $9 / 28(32.1 \%)$ & $18 / 80(22.5 \%)$ \\
\hline
\end{tabular}

TABLE 3. Survey results showing the numbers of participants who said they would be willing to have sex without a condom, by time in service and stratum. In the three right-hand columns, the numbers shown represent the number of sex workers who said they would over the total number of workers and the percentage willing to have sex without a condom

\begin{tabular}{lccc}
\hline $\begin{array}{l}\text { Time in } \\
\text { service }\end{array}$ & Lower stratum & Higher stratum & \multicolumn{1}{c}{ Total } \\
\hline$\leq 12$ months & $1 / 7(14.3 \%)$ & $9 / 20(45 \%)$ & $10 / 27(37.0 \%)$ \\
$>12$ months & $17 / 43(39.5 \%)$ & $19 / 38(50 \%)$ & $36 / 81(44.4 \%)$ \\
Total & $18 / 50(36.0 \%)$ & $28 / 58(48.3 \%)$ & $46 / 108(42.6 \%)$ \\
\hline
\end{tabular}

TABLE 4. Survey results showing the numbers of participants who said they would be willing to have sex without a condom, by stratum and STD history over the two years preceding the survey. In the three right-hand columns, the numbers shown represent the number of sex workers who said they would over the total number of workers and the percentage willing to have sex without a condom

\begin{tabular}{lrrr}
\hline $\begin{array}{l}\text { History } \\
\text { of STD }\end{array}$ & Lower stratum & Higher stratum & \multicolumn{1}{c}{ Total } \\
\hline Yes & $9 / 16(56.3 \%)$ & $7 / 11(63.6 \%)$ & $16 / 27(59.3 \%)$ \\
No & $9 / 34(26.5 \%)$ & $21 / 47(44.7 \%)$ & $30 / 81(37.0 \%)$ \\
Total & $18 / 50(36.0 \%)$ & $28 / 58(48.3 \%)$ & $46 / 108(42.6 \%)$ \\
\hline
\end{tabular}

if the study subjects were representative of all female sex workers in Georgetown, that between a one-sixth and one-third of the latter are infected with HIV.

Of course, it needs to be acknowledged that willingness to participate in the study could have been influenced by pressure from hotel managers and bar owners, good rapport with the port health authorities, and peer pressure exerted by other female sex workers; and that payment to the sex workers (remuneration for time spent) could also have led to some selection bias, especially among certain participants in the lower stratum who requested subsequent interviewer visits to ensure that colleagues participated. One should also note the small numbers sampled in some categories as a result of stratification. In general, there is no reason to presume that the results apply to all female sex workers in Guyana; but it seems reasonable to conclude that they do provide worthwhile information about risk perceptions, risky behaviors, and HIV seroprevalences among those who work in Georgetown. 
All but one of the study participants, all of whom were over 15 years old, had received primary school education. This finding agrees with national statistics indicating that Guyana's literacy level is close to $90 \%$. Regarding racial backgrounds, the participants were $37 \%$ African, 37\% East Indian, $10.2 \%$ Amerindian, and $15.8 \%$ of mixed racial origins. Since Amerindians are estimated to account for a very small percentage of Guyana's population, the fact that over $10 \%$ of the prostitutes studied were Amerindians points up the special difficulties confronted by this group in preparing for and obtaining gainful employment after moving to the city from hinterland areas where educational and other opportunities are not equal.

HIV infections were detected among subjects belonging to all of the ethnic groups studied. Over $60 \%$ of the participants were born in the DemeraraMahaica Region, where Georgetown is located; but the study population included people born in all 10 regions of Guyana. HIV positives were found among women of the DemeraraMahaica Region and four other regions.

In general, participants charging lower fees tended to have more clients per week, and the observed rate of HIV positivity tended to increase with the number of clients. Although condom use is considered important, not much more than half the participants had condoms available for use by clients. At the same time, Guyanese clients appear less likely than foreigners to have condoms and more likely than foreigners to be transmitting or receiving the virus. Hence, there is a need to make much greater educational efforts in Guyana and to counter the myth that the virus is being circulated by foreigners. After several years of discussion, one assumes there is a general understanding that condom use is one way of reducing the risk of HIV transmission. However, it also seems quite obvious that there is a great need for further condom promotion and marketing in Guyana.

The HIV seroprevalence was lower among female sex workers with a longer time in service. This contrasts somewhat with another study among lower socioeconomic strata prostitutes in Nairobi, Kenya, that found higher seropositivity among those with a longer period in prostitution (4). In Georgetown, this could reflect longer experience in prostitution being associated with higher self-esteem or greater professional knowledge-as suggested by the fact that those with less time in prostitution were more disposed to provide services if the client did not want to use a condom.

Most of the study participants felt they would lose clients if they tried to enforce condom use; however, those who said they would have sex without a condom were also more likely to have a positive history of STD.

The HIV seroprevalence was somewhat lower (22\% versus $30 \%$ ) among those who felt they were at risk of contracting HIV than among those who felt they were not. Although this difference was not statistically significant, it suggests that people who are concerned may tend to take greater precautions than those who are not. One must also bear in mind the possibility that participants gave responses which they felt would please the interviewers.

Overall, the participants' knowledge of AIDS and HIV transmission was unsatisfactory. Only 22 (20.4\%) were aware that, at present, there is no known cure for a person who develops AIDS.

Although most of the participants said economic motives determined their decision to become prostitutes, a good deal of illicit drug use was reported to the interviewers. Hence, it appears there could be some relationship between serving as a prostitute and satisfying drug needs.

Overall, fewer survey participants in the higher stratum were aware that free condoms were available at the Genitourinary Medicine Clinic and the Guyana Responsible Parenthood Association; and all the seropositives in the higher stratum lacked this knowledge. The fact that those in the higher stratum had less knowledge about condom availability probably reflects use of the free public health service by those in the lower stratum.

It should also be noted, however, that some of those in the higher stratum who traveled overseas had the experience (in some foreign territories where they operated) of having to report to the public health system for medical permits. That experience could be related to their having acquired information about free condoms in Guyana. More broadly, a number of the survey participants were of the opinion that they should be registered, have occasional medical check-ups, and receive certificates of health that would permit them to operate openly, as is done in some neighboring territories.

Changes to the law on marketing of sex may need to be considered. In the meantime, however, ongoing HIV transmission and the subsequent occurrence of AIDS cases in Guyana has created an urgent need for action among both female commercial sex workers and their clients. That is, concerted efforts should be made to promote behavior modification, increase condom availability and accessibility, provide STD care, clearly explain ways to avoid HIV and STD infection, and increase awareness of the magnitude of the HIV/AIDS/STD problem in the country by providing appropriate and timely information.

Acknowledgments. We would like to thank Dr. Lloyd Godette, Ms. Carol Trotman, and the staff of the National Laboratory for Infectious Diseases in Georgetown for laboratory analysis of the samples. Gratitude is also extended to the following personnel of the Pan American Health Organization in Georgetown: Mr. Peter Carr (country representative), Dr. Fred Nunes, and the late Dr. Eliécer Peña for their revision of the document and encouragement throughout the study; Ms. Indra Beharry-Lall, who assisted with typing; and Mr. Wilton Bailey, who drove the bus. In addition, we wish to thank Dr. Paloma Cuchí of 
PAHO Washington for encouragement throughout the study. Special thanks are also given to officials of
Guyana's Ministry of Health and to the study participants, without whose willing collaboration this study would not have been possible. The cost of the study was defrayed by the National AIDS Program of Guyana.

\section{REFERENCES}

1. Pan American Health Organization/ World Health Organization. AIDS surveillance in the Americas. Washington, DC: $\mathrm{PAHO} / \mathrm{WHO}$; December 1992. [Quarterly report].

2. Mann J. Global AIDS: epidemiology, impact, projections, global strategy. In: World Health Organization. AIDS prevention and control. Geneva: WHO; 1988:3-14.

3. Guyana, Bureau of Statistics. Guyana Stat Bull 1992:5.

4. Simonsen JN, Plummer FA, Ngugi EN, et al. HIV infection among lower socioeconomic strata prostitutes in Nairobi. AIDS 1990;4:139-144.

5. McKeganey N, Barnard M. Selling sex: female street prostitution and HIV risk behaviour in Glasgow. AIDS-Care 1992;4(4):395-407.

6. Hernández-Aguado I, Fernández-García E, García de la Hera M, Álvarez-Dardet C. Infección por el virus de la inmunodeficiencia humano tipo 1 en prostitutas y factores de riesgo. Med Clin Barc 1992; 99(11):406-409.

7. Rehle T, Brinkmann UK, Siraprapsiri T, Coplan P, Aiemsukawat C, Ungchusak K. Risk factors of HIV 1 infection among female prostitutes in Khon Kaen, Northeast Thailand. Infection 1992;20(6):328-331.
8. Gwede C, McDermott RJ. AIDS in subSaharan Africa: implications for health education. AIDS Educ Prev 1992;4(4): 350-361.

9. Wong ML, Tan TC, Ho ML, Lim JY, Wan S, Chan R. Factors associated with sexually transmitted diseases among prostitutes in Singapore. Infect I STD-AIDS 1992;3(5):332-337.

10. Modan B, Goldschmidt R, Rubinstein E, Vonsover A, et al. Prevalence of HIV antibodies in transsexual and female prostitutes. Am J Public Health 1992;82(4): 590-592.

11. Pickering H, Todd J, Dunn D, et al. Prostitutes and their clients: a Gambian survey. Soc Sci Med 1992;34(1):75-88.

12. Wynall FS, Hyams KC, Phillips IA, et al. Sexual transmission of human T-lymphotropic virus type 1 in Peruvian prostitutes. J Med Virol 1992;38(1):44-48.

13. Plourde PJ, Plummer FA, Pepin J, et al. Human immunodeficiency virus type 1 infection in women attending a sexually transmitted disease clinic in Kenya. $J$ Infect Dis 1992;166(1):86-92.

14. Jackson L, Highcrest A, Coates RA. Varied potential risks of HIV infection among prostitutes. Soc Sci Med 1992;35(3): 281-286.
15. Anonymous. Street outreach for STD HIV prevention, Colorado Springs, Colorado, 1987-1991. MMWR 1992;41(6): 94-95, 101.

16. Dorfman LE, Derish PA, Cohen JB. Hey girlfriend: an evaluation of AIDS prevention among women in the sex industry. Health Educ Q 1992;19(1):25-40.

17. Day S. Editorial review: prostitute women and AIDS (anthropology). AIDS 1988;2: 421-428.

18. Padian N. Editorial review: prostitute women and AIDS (epidemiology). AIDS 1988;2:413-419.

19. George JR, Schochetman G. Detection of HIV infection using serologic techniques. In: Schochetman G, George JR, eds. AIDS testing: a comprehensive guide to technical, medical, social, legal, and management issues. New York: Springer Verlag; 1994:62-102.

Manuscript received 9 February 1995. Accepted for publication, following revision, on 14 November 1996. 
RESUMEN En abril de 1993 se llevó a cabo un estudio de 108 trabajadoras sexuales que ejercían la prostitución en Georgetown, Guyana. En el estudio se investigaron, mediante entrevistas y exámenes de sangre, las relaciones entre seroprevalencia de VIH y conocimientos sobre el sida, comportamientos riesgosos, características de los clientes y uso de condones. Las trabajadoras sexuales callejeras —en contraste con las que trabajaban en bares, hoteles y en Port Georgetown - por lo general cobraban menos, estaban en peor situación económica y tenían clientes en circunstancias similares. Por lo tanto, se clasificaron como pertenecientes a un estrato socioeconómico más "bajo", mientras que las otras trabajadoras se clasificaron como de estrato más "alto". En todo el grupo de trabajadoras sexuales se encontró una seroprevalencia general de $25 \%$ (95\%IC: $17 \%-33 \%)$. Las 50 mujeres clasificadas como de estrato bajo tenían una seroprevalencia relativamente alta (42\%, comparada con $10 \%$ en el estrato alto), y a ese subgrupo pertenecían 21 de las 27 seropositivas a VIH. Según la información dada por las participantes, también se relacionaban con esos estratos el origen de los clientes (guyaneses o extranjeros), el consentimiento a tener relaciones sin condón y el uso de condón por los clientes. Las participantes de estrato alto consentían más a menudo a tener sexo sin condón. Las mujeres de ambos estratos tenían pocos conocimientos acerca de la causa del sida y la transmisión de VIH y un número importante de las trabajadoras declaró haber contraído alguna enfermedad de transmisión sexual o consumido drogas ilegales en los 2 años anteriores. Los clientes guyaneses usan condones menos que los extranjeros, lo que sugiere un riesgo más alto de adquirir VIH de esos clientes y también de infectarlos con el virus. La seroprevalencia de VIH fue más alta entre las trabajadoras que dijeron haber tenido clientes guyaneses que entre las que recibían solamente a clientes extranjeros. Fue además estadísticamente mayor entre las que tenían más de cinco clientes a la semana. La seropositividad a VIH fue relativamente alta entre las 12 trabajadoras que declararon haber usado cocaína. En general, los resultados de este trabajo sustentan el principio de que deben fortalecerse las intervenciones dirigidas a las trabajadoras sexuales y sus clientes. En particular, debe hacerse un esfuerzo para intensificar la promoción, distribución y mercadeo social de los condones; mejorar los servicios de enfermedades de transmisión sexual que ofrecen tratamiento y orientación personal a las trabajadoras sexuales y aumentar las actividades educativas dirigidas a los clientes guyaneses. 